Szczepan Szpoton CM

(1) hitps://orcid.org/0000-0002-2609-256x

\title{
Katarzyna Labouré - święta życia ukrytego
}

(doi) https://doi.org/10.15633/9788374389778.02

Wielu myślało, że aby zostać świętym należy posiadać niezwykłe umiejętności, wielorakie talenty czy wszechstronne zdolności - subtelna iluzja!

Kto chciałby znaleźć coś podobnego w życiu Katarzyny Labouré, szukałby na próżno i mógłby rzec: „Trudna jest ta mowa” (J 6, 60).

Katarzyna nie założyła żadnego zgromadzenia, nie ukończyła wyższych studiów - z wielkim trudem te podstawowe. Nigdy nie pełniła znaczącej funkcji we wspólnocie sióstr. Można byłoby stwierdzić, że „nie zrealizowała się w życiu”. To nie zaskakuje oczu, które „patrząc, nie widzą” (Mt 13, 13), Katarzyna to duchowa córka św. Wincentego a Paulo - przyjaciela ubogich!

\section{Rodzina Katarzyny}

Piotr Labouré, ojciec Katarzyny, chciał zostać kapłanem, jednak gdy miał 22 lata, rewolucja francuska uniemożliwiła mu dalszą naukę. Po powrocie $z$ seminarium do swoich rodzinnych stron zajmował się uprawą roli i hodowlą zwierząt. Piastował nawet przez kilka lat urząd mera w Fainlès-Moutiers (Burgundia - departament Côte d'Or), który objął po swoim krewnym - Mikołaju Labouré. Matka Katarzyny, Ludwika Magdalena Gontard, pochodziła z Senailly, gdzie pracowała jako guwernantka. Była niezwykle pobożną kobietą. Piotr i Ludwika Magdalena pobrali się 4 czerwca 1793 roku. Pierwsze siedem lat małżeństwa spędzili w Senailly i tam też na świat przyszły ich pierwsze dzieci. W 1800 roku rodzina Labouré przeniosła się do Fain-lès-Moutiers, gdzie osiadła już na stałe i doczekała się kolejnego potomstwa. 
Katarzyna urodziła się w piątek 2 maja 1806 roku. W domu nazywano ją Zoé, od świętej patronki dnia jej urodzenia. Została ochrzczona nazajutrz, 3 maja, w święto Znalezienia Krzyża Świętego, a ochrzcił ją o. Grzegorz Mamer, dawny benedyktyn z Moutiers, zastępujący tego dnia proboszcza. W latach 1794-1809 Piotr i Ludwika Magdalena Labouré doczekali się siedemnaściorga dzieci, niestety przeżyło jedynie dziesięcioro - trzy córki i siedmiu synów ${ }^{1}$.

Państwo Labouré dają się poznać jako rodzina religijna, w której od najmłodszych lat uczono dzieci takich wartości jak: modlitwa, prawość, szacunek dla innych, czy umiłowanie sumiennej pracy. Labouré byli również jedną z najbogatszych rodzin w swojej miejscowości i dzięki nim została odnowiona kaplica Najświętszej Panny w Fain. To w niej młodziutka Zoé spędzała wiele czasu na prywatnej modlitwie. Już jako dziecko odznaczała się niezwykłym usposobieniem, uchodziła za grzeczną i niesprawiającą nikomu przykrości. Miała piękne, niebieskie oczy, w których odbijała się głębia jej wnętrza - przez całe życie przykuwały one uwagę innych osób ${ }^{2}$. Niestety, po pierwszych radosnych latach życia Katarzyna musiała pożegnać się z najbliższą dla niej osobą - matką. Ciężka praca w domu i w gospodarstwie tak wyczerpały panią Labouré, że podupadła na zdrowiu i 9 października 1815 roku w wieku czterdziestu kilku lat umarła, osieracając dziewięcioletnią Katarzynę. Magdalena była tak zapracowana, że nie zdążyła nauczyć swoich najmłodszych dzieci czytać ani pisać. Przez długie lata Katarzyna wstydziła się, że nie potrafi napisać nawet swojego nazwiska ${ }^{3}$. Doświadczając braku matki, dziewczynka obejmuje figurkę Najświętszej Maryi Panny i prosi, aby to Ona zechciała zastąpić jej ziemską matkę: „Teraz Ty bądź moją matką” - mówi. Jak wiemy z dalszych losów Katarzyny, Matka Boża wysłuchała tej prośby w cudowny sposób ${ }^{4}$.

1 Por. E. Cassinari, La beata Caterina Labouré della Compagnia delle Figlie della Carità, Rzym, s. 15-18; R. Laurentin, Vie de Catherine Labouré. Voyante de la rue du Bac et servante des pauvres 1806-1876, t. 1: Récit, Paris 1980, s. 14-15; W. Rakocy, Św. Katarzyna Labouré i Cudowny Medalik, Kraków 2017, s. 9-10.

2 Por. W. Rakocy, Św. Katarzyna Labouré i Cudowny Medalik, dz. cyt., s. 10.

3 Por. R. Laurentin, Powiernica Niepokalanej, Kraków 1982, s. 8.

4 Por. E. Cassinari, La beata Caterina Labouré della Compagnia delle Figlie della Carità, dz. cyt., s. 19. 
Śmierć matki zmieni także życie Marii Ludwiki, najstarszej siostry Katarzyny. Musiała bowiem opuścić pensję w Langers i zastąpić matkę w gospodarstwie, stając się gospodynią domu. Aby odciążyć Marię Ludwikę z obowiązku wychowywania najmłodszego rodzeństwa, ojciec postanawia odesłać Katarzynę i Toninę do ciotki Małgorzaty w Saint Rémy, która okazała się jednak zajęta pracą (handlem) i nie mogła oddać się wyłącznie opiece nad dziećmi. Katarzyna stara się więc wypełnić pustkę po stracie matki zaangażowaniem w każdą pracę, którą wykonuje w Saint Rémy i codziennie uczy się żyć w wewnętrznej samotności. Jednak Piotr Labouré, nie tyle z tęsknoty, ile z potrzeby, sprowadza dwunastoletnią Katarzynę i dziesięcioletnią Antoninę do domu rodzinnego. Najstarsza z córek, Maria Ludwika, w czerwcu 1818 roku, mając dwadzieścia trzy lata, wstępuje do Zgromadzenia Sióstr Miłosierdzia i odbywa postulat w Langres. Katarzyna jako młoda dziewczyna przejmuje jej obowiązki w gospodarstwie. Mimo swojego wieku okazuje przy tym niezwykłą dojrzałość i zaradność 5 .

Powrót Katarzyny do rodzinnego domu stał się podwójnym świętem: radością spotkania z ojcem i przystąpieniem po raz pierwszy do Komunii świętej, wyznaczonej na 25 stycznia 1818 roku. Antonina wspomina, że jej starsza siostra po przyjęciu Eucharystii wyglądała, jakby już nie należała do tej ziemi. Wkrótce po tym wydarzeniu Katarzyna powie Antoninie: „Ja też będę Siostrą Miłosierdzia, tak jak Maria Ludwika”6.

Dzień Katarzyny rozpoczynał się o czwartej rano, a kończył wieczorną modlitwą. Jako gospodyni zajmowała się przygotowaniem posiłków, w czasie żniw nawet dla kilkunastu osób, ale także oporządzaniem zwierząt, wyrabianiem ciasta drożdżowego na chleb, paleniem w piecu, udawaniem się w każdy czwartek na targ do odległego o piętnaście kilometrów Montbard, robieniem prania, szyciem, sprzątaniem i zmywaniem.

5 Por. tamże, s. 20-22.

6 Święta życia ukrytego, Katarzyna Labouré, Siostra Miłosierdzia, Kraków 1977, s. 5. Waldemar Rakocy, opisując silny charakter Katarzyny i powagę obranej przez nią drogi, nawiązuje do jej relacji ze starszą siostrą: „Kiedy w 1834 roku starsza od niej o jedenaście lat Maria Ludwika opuściła Zgromadzenie Sióstr Miłosierdzia, Katarzyna spakowała listy, jakie otrzymywała od niej i wysłała jej, aby przeczytała sobie, jaka kiedyś była szczęśliwa. Maria Ludwika opuściła zgromadzenie w wyniku bolesnego oszczerstwa pod jej adresem, ale również z powodu dumy, która nie pozwoliła jej znieść z pokorą trudnej sytuacji. Wróciła do wspólnoty w 1845 roku, zmarła zaś siedem miesięcy po Katarzynie, 25 lipca 1877 roku”. W. Rakocy, Św. Katarzyna Labouré i Cudowny Medalik, dz. cyt., s. 14-15. 
Ojciec, obawiając się, że nadmiar obowiązków przerośnie młodą gospodynię, zatrudnił kobietę z sąsiedztwa, która miała wspomóc ją i jej młodszą siostrę. Jednak szybko zostaje ona zwolniona, gdyż siostry Labouré doskonale wywiązują się ze swoich obowiązków. To zaangażowanie w pracę na trwale ukształtuje ich charaktery i pozwoli podejmować w przyszłości każdą misję - szczególnie jeśli chodzi o Katarzynę i jej posługę wśród ubogich?

W czym tkwi sekret młodej gospodyni, która jest panią i służącą zarazem? Tajemnica Katarzyny kryje się w jej „ucieczkach” z gospodarstwa. Dziewczyna znika codziennie na długie chwile. Jej miłość kryła się w kościele w Fain, w którym Katarzyna klęczała na kamiennej posadzce przed obrazem Niepokalanej w odrestaurowanej przez jej rodzinę kaplicy. Tam właśnie czerpie pogodę ducha i siłę do uczciwego wykonywania swoich obowiązków. Tam też dojrzewa jej powołanie. Nawet gdy tabernakulum było puste, uczyła się odnajdywać obecność Pana w głębi swojego serca, ale również, a nawet bardziej, w ubogich, których przyjmuje, oraz w chorych, których odwiedza. To niezwykle wyraźny rys jej życia - mocny, przejrzysty ${ }^{8}$.

Ponadto Katarzyna:

w wieku czternastu lat postanawia pościć każdego piątku i soboty. Nie wiemy, jak surowy był ów post, lecz zapewne na tyle, iż ojciec zaniepokojony tym, zdecydowanie jej go zabronił. Katarzyna najpierw zaczęła się ukrywać ze swą praktyką, lecz po pewnym czasie ojciec ustąpił. Z przerwami, jak okres seminarium, wytrwała w swym postanowieniu do końca życia ${ }^{9}$.

\section{Powołanie}

Pewnej nocy powołanie i zarazem wezwanie przybiera dla Katarzyny formę marzenia sennego:

7 Por. R. Laurentin, Powiernica Niepokalanej, dz., cyt., s. 18-19.

8 Por. tamże, s. 22.

9 W. Rakocy, Św. Katarzyna Labouré i Cudowny Medalik, dz. cyt., s. 16. 
Byłam w kościele w Fain. Modliłam się. Nagle pewien starszy ksiądz w czarnej piusce zbliżył się do ołtarza i zaczął odprawiać Mszę. Wpatrywał się we mnie uparcie. Pod koniec mszy dał mi znak, bym się przybliżyła. Bałam się. Zaczęłam się cofać, nie odrywając od niego wzroku. Po wyjściu z kościoła poszłam odwiedzić chorego. Starszy kapłan był tam również i powiedział: „Moja córko, dobrze jest pielęgnować chorych. Teraz ode mnie uciekasz, ale pewnego dnia będziesz szczęśliwa, gdy do mnie przyjdziesz. Bóg ma wobec Ciebie pewien plan. Nie zapomnij o tym"10.

Sen spowodował u Katarzyny nowy zryw. Swoje obowiązki na gospodarstwie zaczęła wykonywać jeszcze sumienniej niż przedtem, ale była przy tym jakby nieobecna. Powołanie zaczęło znacznie mocniej w niej pulsować. Pewnego dnia odwiedza ze swoją bratową wspólnotę sióstr miłosierdzia w Châtillon. W rozmównicy widzi portret starszego księdza, przed którym uciekała. Zapytała więc, kim jest ów kapłan, a w odpowiedzi usłyszała, że to św. Wincenty a Paulo. Od tamtego momentu pielęgnuje w sobie jeszcze silniejsze pragnienie zastania Siostrą Miłosierdzia. Czyż nie jest to wyraz wdzięczności względem Ojca ubogich, że zechciał ją mieć w założonym przez siebie Zgromadzeniu Sióstr Miłosierdzia ${ }^{11}$ ? Katarzyna, by wstąpić do zgromadzenia, musi umieć co najmniej czytać i pisać - taki warunek przyjęcia jej postawiono. Płaci więc trzydzieści franków w złocie (całe swe oszczędności) osobie, która uczy ją podpisywać się. Ale to jednak nie wystarczy. Kiedy Katarzyna ma osiemnaście lat, Antonina Gontard, kuzynka od strony matki, zabiera ją do pensjonatu w Châtillon-sur-Seine, by mogła tam nauczyć się czegoś więcej. Jej młodsza siostra Tonina ma wówczas już szesnaście lat i jest wystarczająco zaradna, by zarządzać rodzinnym gospodarstwem. Mimo uprzedzeń ojciec godzi się na wyjazd Katarzyny, wie bowiem, że najstarsze dzieci otrzymały odpowiednie wykształcenie, a najmłodsze, z powodu śmierci matki, niestety nie. W 1824 roku dziewczyna wyjeżdża do Châtillon-sur-Seine, by podjąć naukę ${ }^{12}$.

Po powrocie do Fain Katarzyna na nowo podejmuje pracę w gospodarstwie. W dniu swoich 21 urodzin dzieli się z ojcem rozeznaniem swojego powołania i pragnieniem wstąpienia do Zgromadzenia Sióstr Miłosier-

10 A. Prévost, Katarzyna Labouré. Powiernica Nieba, Paryż 2005, s. 6.

11 Por. W. Rakocy, Św. Katarzyna Labouré i Cudowny Medalik, dz. cyt., s. 17.

12 Por. R. Laurentin, Vie de Catherine Labouré, dz. cyt., s. 45-49. 
dzia. Ojciec stanowczo odmawia i decyduje, że wyda ją za mąż. Katarzyna jednak odmawia wszystkim kandydatom i niewzruszenie trwa przy Bogu. Jej brat Karol, który miał restaurację w Paryżu, w 1828 roku utracił żonę. Ojciec zatem posyła Katarzynę do pracy w stolicy, nastawiając jednocześnie Karola, by ten postarał się, aby przez zmianę środowiska zmieniła swoje zdanie na temat wstąpienia do zgromadzenia. Nie odnajdując się w paryskim towarzystwie, dziewczyna przeżywa wewnętrzne cierpienie, ale jednocześnie wzmacnia swoją więź z Bogiem. Nie mija rok, a Karol żeni się po raz drugi. Katarzyna nie może nie skorzystać z okazji, by wyjechać z Paryża. Pisze zatem do swojej starszej siostry Marii Ludwiki o swoim powołaniu, a ta doradza jej, aby wróciła do Châtillon-sur-Seine i kontynuowała naukę. Tak też się dzieje jesienią 1829 roku. W tym czasie kuzynka Gontard poślubia najstarszego brata Katarzyny, Huberta i oboje wstawiają się w sprawie jej powołania u ojca, który w końcu ulega. Warto dodać, że ojciec na tyle sprzeciwiał się decyzji córki, że w żaden sposób nie uposażył jej w posag. Jednak i w tej sprawie mogła liczyć na brata i bratową. Mimo tych przeciwności był to jeden ze szczęśliwszych dni przyszłej wizjonerki ${ }^{13}$.

\section{Seminarium}

W styczniu 1830 roku Katarzyna rozpoczyna postulat w domu sióstr miłosierdzia w Châtillon. Z wielką pokorą podejmuje codzienne obowiązki, okazując przy tym swoją wielkie zaangażowanie. W każdą niedzielę i czwartek pracuje w kuchni dla ubogich, którzy przychodzą i zabierają zupę dla swoich rodzin i dla chorych ${ }^{14}$. Jedna $z$ tamtejszych sióstr, Wiktoria Séjole, obserwując Katarzynę podczas kilkumiesięcznego postulatu, powiedziała siostrze Marii-Klemencji Caseneuve, zeznającej w procesie diecezjalnym: „Jeszcze nigdy w swoim życiu nie widziałam duszy tak czystej i niewinnej. To dziecko zasługuje na łaski ze strony nieba"15. Katarzy-

\footnotetext{
13 Por. W. Rakocy, Św. Katarzyna Labouré i Cudowny Medalik, dz. cyt., s. 19-2o.

14 Por. R. Laurentin, Vie de Catherine Labouré, dz. cyt., s. 51.

15 Por. R. Laurentin, Catherine Labouré et la Médaille Miraculeuse. Procès de Catherine, Paris 1979, s. 170; W. Rakocy, Św. Katarzyna Labouré i Cudowny Medalik, dz. cyt., s. 20.
} 
na od pierwszych dni swojej formacji jest całkowicie poddana działaniu woli Bożej.

Następnie Katarzyna wyjeżdża do Paryża, by tam 21 kwietnia rozpocząć seminarium i by na nowo mogły realizować się słowa wypowiedziane przez św. Wincentego:

Po co opuściłyście swoje okolice, rodziców, ojcowiznę? By ukochać naszego Pana i Jego zasady! Jesteście Jego córkami, a on jest Waszym Ojcem. On Was zrodził i dał Wam swego ducha. Kto bowiem zapoznał się z życiem Chrystusa, zobaczy niewątpliwie Jego podobieństwo w życiu Siostry Miłosierdzia ${ }^{16}$.

Tym chętniej opowiem wam o przymiotach dobrych wieśniaczek, bo znam je z doświadczenia i z natury. Jestem przecież synem niezamożnego rolnika i żyłem na wsi aż do piętnastego roku życia. Na dodatek, od wielu lat pracujemy wśród ludności wiejskiej. Nikt więc nie zna ich lepiej niż księża Zgromadzenia Misji. Nie ma wartościowszych ludzi nad tych, którzy rzeczywiście mają usposobienie wieśniaków. U nikogo nie znajdziemy gorętszej niż u nich wiary, bardziej ufnego zwracania się do Boga w potrzebach, szczerszego podziękowania Mu w czasie pomyślności ${ }^{17}$.

Wszystko wygląda tak, jakby sam św. Wincenty czekał na Katarzynę. Kilka dni po przybyciu do Paryża jego relikwie, ukrywane w czasie rewolucji w katedrze Notre Dame, zostają zwrócone przez arcybiskupa misjonarzom. W niedzielę 25 kwietnia zostają przeniesione do domu św. Łazarza. W uroczystej procesji uczestniczy król, a także tysiąc sióstr miłosierdzia i sto dwanaście seminarzystek, wśród nich Katarzyna Labouré ${ }^{18}$.

Dziś śmiało możemy powiedzieć, że po okresie rewolucyjnych rozruchów, Opatrzność powołała nową Małgorzatę Naseau, by ożywić gorliwość, pobudzić ducha i rozpalić nowy zapał misyjny - jak w początkach zgromadzenia.

Podczas pobytu w seminarium Katarzyna ponownie spotyka św. Wincentego - tym razem na jawie. Czyżby św. Wincenty osobiście chciał ją

16 Św. Wincenty a Paulo, Listy, konferencje, dokumenty, t. 9, tłum. K. Potok, Kraków 2016, s. 539.

17 Tamże, s. 78.

18 Por. N. Storti, Documento inedito sulla vita di Caterina Labouré in ricordo di Maria Storti, „Annali della Missione" 2 (1978), s. 142-153. 
prowadzić w powołaniu? Katarzyna widzi serce św. Wincentego całkowicie oddane Chrystusowi i ubogim. W trzech wizjach ksiądz Wincenty nakreśla jasny plan formacji: „Moje córki, wy wszystkie powinniście być dobrymi chrześcijankami. Tak jakby chciał wprowadzić Katarzynę w samą istotę objawienia Boga, który jest Miłością $(\mathrm{J} 4,8)^{19 ”}$.

Wizja serca o białym kolorze oznacza pokój, jaki daje Bóg. Konieczność przyjęcia Księcia Pokoju, Jezusa, jest niezbędna, by nieść pokój ubogim. Stanowi to jednocześnie przypomnienie o konieczności słuchania i odpowiadania na wołanie ubogich, budując przy tym bardziej sprawiedliwe i braterskie człowieczeństwo. W czasie kolejnej wizji serca, tym razem o kolorze ogniście czerwonym, Wincenty ukazuje Katarzynie płomień swojej miłości do Chrystusa i gorącej miłości ogarniającej wszystkich ubogich. Katarzyna rozumie, że oba zgromadzenia powinny się odnowić, wrócić do swych korzeni, do swojej najgłębszej tożsamości, by móc zapalać ogień miłości na całym świecie. Serce koloru czerwono-czarnego może oznaczać cierpienie. Katarzynie przypomina ono nieszczęście ubogich, przelew krwi we Francji oraz smutek wieszczący nadchodzące wydarzenia polityczne ${ }^{20}$.

Seminarzystka Labouré doświadcza jeszcze wielu innych łask. Przez cały okres formacji z wyjątkiem dni, w których, jak pisze, wątpiła, widzi Jezusa w Najświętszym Sakramencie ${ }^{21}$. Ponadto w uroczystość Trójcy Świętej, 6 czerwca 1830 roku, Pan ukazuje jej się ukrzyżowany, pozbawiony szat. Katarzyna utożsamia Chrystusa ukrzyżowanego z całą ludzkością, która cierpi, z ofiarami nędzy, wykorzystywania i ucisku we wszystkich częściach świata. Czuje się wezwana przez Boże współczucie do troski o Brata w człowieczeństwie ${ }^{22}$.

Szczególną łaską, jakiej dostąpiła Katarzyna w trakcie seminarium, były spotkania z Najświętszą Maryją Panną. Z pierwszą wizytą Matka Boża przychodzi 18 lipca 1830 roku, w wigilię uroczystości św. Wincentego. Katarzyna wspomina to wydarzenie w następujący sposób: „Ujrzawszy Najświętszą Dziewicę, jednym susem znalazłam się przy Niej, położyłam swe ręce na jej kolanach”. Następnie słyszy: „Cały świat będzie pogrążo-

19 Por. R. Laurentin, Prawdziwe życie Katarzyny Labouré, Kraków 1995, s. 58-66.

20 Tamże.

21 Por. W. Rakocy, Św. Katarzyna Labouré i Cudowny Medalik, dz. cyt., s. 23.

22 Por. R. Laurentin, Prawdziwe życie Katarzyny Labouré, dz. cyt., s. 66-72. 
ny w nieszczęściach. Krzyż będzie w pogardzie. Tron będzie wywrócony”. Kolejno Matka Najświętsza wypowiada słowa, które uczyniły kaplicę przy ulicy du Bac miejscem już na zawsze uprzywilejowanym: „Ale przychodźcie do stopni tego ołtarza. Tutaj łaski zostaną udzielone wszystkim, którzy o nie proszą z ufnością i żarliwością, na małych i na wielkich”. To przesłanie, wyryte w pamięci wielu, szczególnie wśród członków rodziny wincentyńskiej, przyciąga licznych wiernych do tego szczególnego miejsca kultu maryjnego, jakim jest kaplica Cudownego Medalika w Paryżu ${ }^{23}$.

Podczas drugiej wizji, 27 listopada 1830 roku, Matka Boża objawia swoje Niepokalane Poczęcie. Z dłoni Najświętszej Dziewicy spływają płomienie będące „symbolem łask, które Maryja wyprasza dla ludzi”. Wokół obrazu ukazuje się również napis w kolorze złota „O Maryjo bez grzechu poczęta, módl się za nami, którzy się do Ciebie uciekamy”. Maryja poleca Katarzynie wybicie medalika według tego wzoru i obiecuje, że osoby, które będą go nosić, dostąpią szczególnej opieki Niepokalanej ${ }^{24}$.

Powyższe przesłanie posiada szczególną wartość dla rodziny wincentyńskiej, gdyż to właśnie jedna z sióstr miłosierdzia została wybrana, by przekazać jego treść światu. Objawienie maryjne przy ulicy du Bac w $\mathrm{Pa}$ ryżu jest wyrazem szczególnej miłości, jaką Matka Najświętsza darzy obydwa zgromadzenia. Nie ukrywała Ona również zmartwienia z powodu letniości, mierności i rozluźnienia panującego w obydwu wspólnotach. Wyrażając swoje zatroskanie, zaprasza nas do nawrócenia.

Na szczególną uwagę zasługuje fakt, że poza ks. Aladelem - spowiednikiem Katarzyny - nikt nie wiedział, że to właśnie ona widziała Niepokalaną, że to jej Maryja powierzyła troskę o wybicie i rozpowszechnienie medalu. Modlitwa, obowiązkowość i praktykowanie posłuszeństwa, to chleb powszedni Katarzyny. Była to, jak stwierdził Pius XII podczas beatyfikacji, „święta obowiązku stanu i milczenia”"

Siostra Maria Velay, dyrektorka seminarium, nie zauważyła oczywiście niczego. Na zakończenie czasu formacji wstępnej napisała opinię, w której podkreśla zwyczajny i przeciętny charakter Katarzyny: „Silna, średniego wzrostu. Umie czytać i pisać na własny użytek. Ujawnia dobry charakter.

23 Por. R. Laurentin, Vie de Catherine Labouré, dz. cyt., s. 80-9o.

24 Por. tamże, s. 91-94.

25 Por. Święta życia ukrytego, Katarzyna Labouré, Siostra Miłosierdzia, dz. cyt., s. 17. 
Umysł i osąd nie są wybitne. Jest wystarczająco dysponowana. Pobożna, pracuje bez zarzutu"26.

Na szczególne podkreślenie zasługuje zatem milczenie Katarzyny w związku z objawieniami, nierzadko wystawiane na próbę. W najbliższym jej otoczeniu domyślano się, że to ona jest tą, która miała widzieć Niepokalaną i z tej racji siostry często w bardzo podchwytliwy sposób chciały wymusić z niej jakieś potwierdzenie. Po śmierci Katarzyny opinia sióstr była ciągle spolaryzowana. Jedne mówiły, że to najprawdopodobniej ona była wizjonerką, inne podawały to w wątpliwość. Osobą, która jako pierwsza doszła do przekonania, że to s. Katarzyna doświadczyła owej łaski, była wspomniana wcześniej s. Séjole. Kiedy dowiedziała się, że jednej z seminarzystek ukazała się Najświętsza Panna, miała wykrzyknąć bez namysłu: „To może być tylko s. Labouré. Nikt inny nie jest godzien takiej łaski" ${ }^{27}$.

Natomiast osobą, która w pełni wzięła odpowiedzialność za młodą seminarzystkę i wizjonerkę, był jej spowiednik, ks. Aladel. Ciążyła na nim również odpowiedzialność za przekaz objawienia i jego treści. Od tego, co powiedział, zależało bardzo wiele i to nade wszystko w jego rękach spoczywał los medalika, kiedy sprawa została przedstawiona władzy kościelnej.

\section{Pozostały okres życia w zgromadzeniu}

30 stycznia 1831 roku Katarzyna kończy pobyt w seminarium. Przywdziewa suknię zgromadzenia i nazajutrz wyjeżdża. Zostaje posłana do domu sióstr w podparyskiej miejscowości Reuilly, gdzie 3 maja 1835 roku (po pięciu latach pobytu we wspólnocie), w niedzielę Dobrego Pasterza, w kaplicy w przytułku Enghien składa śluby. Siostry w tym miejscu prowadziły szereg działań na rzecz ubogich: opiekę nad sierotami oraz dwa hospicja. Wykonywały jeszcze wiele innych zajęć związanych z prowadzeniem domu, ogrodem, hodowlą zwierząt czy uprawą roli ${ }^{28}$.

Jednym z pierwszych obowiązków Katarzyny była praca w kuchni, w której przygotowywano posiłki dla ubogich. Po krótkim czasie szyb-

26 R. Laurentin, Prawdziwe życie Katarzyny Labouré, dz. cyt., s. 90.

27 Por. W. Rakocy, Św. Katarzyna Labouré i Cudowny Medalik, dz. cyt., s. 23.

28 Por. R. Laurentin, Vie de Catherine Labouré, dz. cyt., s. 98-10o. 
ko zorientowano się, że Katarzyna potrafi sobie tam doskonale radzić. Jedynym problemem była główna kucharka, trzydziestopięcioletnia siostra Wincenta, założycielka domu, ciesząca się nadzwyczajnym uznaniem przez swoją ascezę i wrażliwość. Była ona jednak skąpa w stosunku do ubogich i ograniczała im porcje do minimum, a nawet dawała to, co było już stare. Dla Katarzyny te ograniczenia były nie do przyjęcia. Dręczyła się tym stanem rzeczy, dlatego też zwróciła się do swojego spowiednika ks. Aladela, aby jej pomógł zmienić dom. Ten jednak nieodmiennie tłumaczył jej: „Trzeba cierpliwe znosić tę towarzyszkę”. Niewątpliwie była to dla Katarzyny droga cnoty, która nie mogła prowadzić w innym kierunku, niż pokora, służba i miłość do ubogich ${ }^{29}$.

Siostra Katarzyna w Reuilly spędza resztę swojego życia - czterdzieści sześć lat. W tym miejscu spełnia rozmaite posługi: pracuje w kuchni, w pralni, w szwalni, w ogrodzie, w oborze, troszczy się o gołębnik, a od 1861 roku także o hospicjum dla mężczyzn - tę posługę traktowała z niezwykłym oddaniem i miłością. Przez ostatnie lata życia ze względu na stan zdrowia ${ }^{30}$ była również furtianką ${ }^{31}$.

Mimo że w hospicjum przebywali bezdomni i chorzy, ludzie często bardzo wulgarni, złośliwi i nadużywający alkoholu, Katarzyna pozostawała wobec nich niezwykle cierpliwa. Jej rzekomą słabością, zdaniem s. Joanny Dufès, było to, że nigdy na nich nie krzyczała ${ }^{32}$. Była dobra nawet dla najbardziej kąśliwych, nazywając ich perłami ${ }^{33}$.

Podczas piętnastu lat pracy w hospicjum tym, co zasługuje na szczególną uwagę, było pozyskiwanie z miłością i wytrwałością podopiecznych

29 R. Laurentin, Prawdziwe życie Katarzyny Labouré, dz. cyt., s. 92.

30 Siostra Katarzyna znalazła się również w szpitalu z powodu bólów ischiasowych, ale ten pobyt miał nie przynieść jej żadnej ulgi. Jedna z sióstr, s. d’Aragon, doskonale wiedziała o dolegliwościach Katarzyny, dając o niej takie świadectwo: „Pod pozorami doskonałego zdrowia, cierpiała i nikt się nad nią nie użalał”. R. Laurentin, Prawdziwe życie Katarzyny Labouré, dz. cyt., s. 118.

31 W. Rakocy, Św. Katarzyna Labouré i Cudowny Medalik, dz. cyt., s. 26.

32 Por. R. Laurentin, Prawdziwe życie Katarzyny Labouré, dz. cyt., s. 124, 215.

33 „Katarzyna sumiennie wypełnia swoje obowiązki. Kiedy od 1861 roku zajmowała się starcami w hospicjum, opróżniała i myła ich nocniki, które przypominały wiadra podstawiane pod krzesło $z$ otworem. Robiła to na dziedzińcu, gdzie był dostęp do wody. Smród rozchodził się na wszystkie strony, a ona powtarzała przechodzącym siostrom, że „to są perły Siostry Miłosierdzia”. Ta, która złożyła dłonie na kolanach Matki Boga, szczyciła się tym, że może spełniać taką posługę. Nie dziwi, że niebo odwzajemniało się jej różnymi łaskami”. W. Rakocy, Św. Katarzyna Labouré i Cudowny Medalik, dz. cyt., s. 29. 
dla Boga. Katarzyna zabiegała o to, aby nigdy nie byli oni głodni, podczas choroby spędzała przy nich noce, kiedy odchodzili zawsze była blisko, a po śmierci modliła się za ich dusze i o to samo prosiła inne siostry ${ }^{34}$.

$\mathrm{Na}$ uwagę zasługuje również charakterystyczny rys duchowości s. Katarzyny, która robiła wszystko, aby nie wyróżniać się w codziennym życiu. W ostatnich swoich latach, kiedy podupadła na zdrowiu i leżała chora w łóżku, s. Franciszka Charvier, będąc prawie pewną, że to s. Katarzyna jest powiernicą Niepokalanej, zapytała ją, dlaczego mając do tego prawo, nie prosi o możliwość codziennego przyjmowania Komunii św. (ta praktyka stała się powszechna dopiero na początku Xx wieku). Usłyszała taką odpowiedź: „Cieszę się, kiedy mi się ją przynosi, lecz wolę ją przyjmować tak często, jak inni. Nie chcę, aby zwracano na mnie uwagę". Niezwykle skromna, nie chciała w niczym się wyróżniać, a przede wszystkim zabiegała o to, aby nikt nie wiedział, która z sióstr dostąpiła łaski spotkania z Matka Bożą ${ }^{35}$.

We wtorek 25 kwietnia 1865 roku umiera ks. Aladel. Katarzyna przeżywa ogromny smutek, ponieważ odszedł ktoś, komu bez reszty ufała. Czuje jednak także niepokój, gdyż przemilczał on wizję Niepokalanej z globem w dłoniach. Wobec zbliżającej się śmierci uważa, że nadeszła chwila przemówienia i że Matka Boża zwalnia ją z sekretu. W 1876 roku (ostatnim roku swojego życia) przerywa milczenie. To właśnie znajomość roku i konkretnego dnia własnego odejścia zmusza ją do opowiedzenia o tym, co przemilczał jej spowiednik. Otwiera się zatem przed swoją przełożoną. s. Joanną Dufès i ks. Julianem Chevalierem. S. Labouré opowiada przede wszystkim o wizji Niepokalanej z globem ziemskim w dłoniach, ponieważ Cudowny Medalik jest już dobrze znany od ponad czterdziestu lat. Katarzyna uprasza też przełożoną, aby wykonano figurę Niepokalanej z globem w dłoniach. Jej autorem był Dezyderiusz Froc-Robert i znajduje się ona po dziś dzień w domu sióstr w Reuilly ${ }^{36}$.

W ostatnich tygodniach życia s. Katarzyna została zapytana przez jedną z sióstr, czy boi się śmierci? W odpowiedzi usłyszała: „Dlaczego miałabym się bać śmierci? Przecież idę spotkać naszego Pana, Najświętszą Pannę, św. Wincentego a Paulo". Będąc na ziemi, żyła niebem. Kiedyś s. Anna

34 Por. tamże, s. 28-29.

35 Tamże, s. 31.

36 Por. Święta życia ukrytego, Katarzyna Labouré, Siostra Miłosierdzia, dz. cyt., s. 20. 
Tranchemer zapytała ją: „Co siostra widzi tam w górze?” Uśmiechnęła się tylko ${ }^{37}$.

Katarzyna zmarła 31 grudnia 1876 roku. „Z trudem spostrzegłyśmy, że już nie żyje, powiedziała potem s. Dufès, nigdy nie widziałam tak lekkiej śmierci"38. Podczas pogrzebu ogłoszono, że to ona została zaszczycona objawieniami Maryi Niepokalanej. 28 maja 1933 roku papież Pius xi zaliczył ją do grona błogosławionych, a papież Pius XII dokonał jej kanonizacji 27 lipca 1947 roku. Jej liturgiczne wspomnienie obchodzone jest 28 listopada, dzień po święcie Cudownego Medalika ${ }^{39}$.

Są święci, którzy pozostają „aktualni” na wszystkie czasy. Aktualni przez swoje życie, aktualni przez posłannictwo, jakie zostało im powierzone przez Boga. Do takich świętych niewątpliwie należy s. Katarzyna Labouré. Mówi do nas swoim prostym, zwyczajnym życiem, zachęcając byśmy nie ulegali pokusie i nie szukali nadzwyczajności. Nie zamyka się w swoim przywileju, ale ofiarując swoje życie na służbę Chrystusowi i ubogim, pozostaje łagodna, spokojna i sumienna we wszystkich powierzonych jej obowiązkach. Odbija się w niej życie Maryi - wierność rzeczom zwykłym, dokładność i uczciwość. Na jej świętość składa się nie tyle przywilej objawień, co wypełnienie charyzmatu, jaki wskazał św. Wincenty a Paulo. To właśnie wierność charyzmatowi świadczy o jej świętości, a świętość sprawia, że charyzmat wincentyński pozostaje wciąż żywy i aktualny.

\section{Abstrakt}

Katarzyna Labouré, święta życia ukrytego

Powyższy tekst opisuje najważniejsze wydarzenia z życia s. Katarzyny. Podzielone zostały na cztery etapy. Pierwszy - dotyczy jej rodziny i wychowania. Drugi - odnosi się do odkrywania i wzrastania w powołaniu. Trzeci - to lata spędzone w seminarium, w którym dostąpiła szczególnej

37 W. Rakocy, Św. Katarzyna Labouré i Cudowny Medalik, dz. cyt., s. 45.

38 Święta życia ukrytego, Katarzyna Labouré, Siostra Miłosierdzia, dz. cyt., s. 20.

39 Por. A. Vernaschi, Dziedzictwo, Kraków 2012, s. 120. 
łaski spotkania z Matką Bożą. Ostatni, najdłuższy (czterdziestosześcioletni), przypada na jej służbę dla ubogich w przytułku Enghien.

Słowa kluczowe: rodzina Katarzyny Labouré, powołanie, objawienia, służba ubogim

\section{Abstract}

Catherine Labouré, saint of the hidden life

The above text describes the major events of Sr. Catherine's life. They are divided into four stages. The first refers to her family and upbringing. The second relates to discovering and growing in her vocation. The third is the years spent in the seminary, where she received the special grace of meeting the Mother of God. The last, and the longest, of 46 years, is in her service to the poor at the Enghien home.

Keywords: Catherine Labouré's family, vocation, revelations, service to the poor

\section{Bibliografia}

1. Cassinari E., La beata Caterina Labouré della Compagnia delle Figlie della Carità, Rzym.

2. Laurentin R., Catherine Labouré et la Médaille Miraculeuse. Procès de Catherine, Paris 1979.

3. Laurentin R., Vie de Catherine Labouré. Voyante de la rue du Bac et servante des pauvres 1806-1876, t. 1: Récit, Paris 1980.

4. Laurentin R., Powiernica Niepokalanej, Kraków 1982.

5. Laurentin R., Prawdziwe życie Katarzyny Labouré, Kraków 1995.

6. Prévost A., Katarzyna Labouré. Powiernica Nieba, Paryż 2005.

7. Rakocy W., Św. Katarzyna Labouré i Cudowny Medalik, Kraków 2017.

8. Storti N., Documento inedito sulla vita di Caterina Labouré in ricordo di Maria Storti, „Annali della Missione” 2 (1978), s. 142-153. 
9. Święta życia ukrytego, Katarzyna Labouré, Siostra Miłosierdzia, Kraków 1977.

10. Św. Wincenty a Paulo, Listy, konferencje, dokumenty, t. 9, tłum. K. Potok, Kraków 2016.

11. Vernaschi A., Dziedzictwo, Kraków 2012. 
Aniwersytet Papieski

ifl Jana Pawta II

(b) wrakowie 